Prabhu tells us early on that "It was around Hindutva politics that we had had our first real fight, over the whole Ayodhya agenda of the BJP... it drove him crazy that I did not see things his way" ( $p$ 29). What is his way of seeing things? Can it be reduced to his condition? SMG lived by a political-theology that synced with right-wing Hindutva politics. He had worked for the RSS and "the rhetoric of sacrifice and self-denial was our father's mainstay" ( $p$ 28). He firmly believed in fate, discipline through violence, philanthropy, raising daughters as sons, and the inherent goodness of man. He eschewed planning, saving money, being professional, and teaching through kindness; he was reckless (and justifiably so, according to him) on the road. His social circle bragged about his capacity to tolerate pain; they considered it courageous. "Everything appealed in its extremes" ( $p$ 80), including the Babri Masjid rampage because his "inherent sense of service could be clothed in the social comfort of Hindu pride and identity" (p 106). In a moment of brave declaration, Prabhu tells us that SGM "danced in front of the screen as frenzied mobs climbed the dome and chipped away at bronzed beautiful stone. I remember something inside me curdling slowly. You cheered the hooligans -- you wished you had been there!.... It was repulsive to me" ( $p$ 106). What Prabhu shares with SGM - mental illness, a passion for storytelling, love for dogs - runs deep, but what Prabhu refuses to share runs deeper in the narrative. Her refusal to inherit his way of seeing things defines the first irreversible chasm in their relationship.

This tension between inheritance, convention, and willful deviation becomes all the more poignant as Prabhu finds a career SGM does not envision for her. There is often a wide dissonance in what parents dream for their children, and what children dream for themselves, and this is true regardless of mental illness and conflicting politics. In this context, If I had to tell it again mindfully leads a much-needed dialogue about parenting - how do you teach mathematics if your child is not interested? What do you do if she is interested but unable to learn? How do you enable her to communicate her feelings, aspirations, and desires? How do you teach her to debate, disagree, question, refuse? How do you nurture a healthy imagination in children? How do you protect them and teach them to protect themselves? In other words, what is good parenting? "There was no awareness that children might end up feeling utterly undeserving if turned into monks who have to hone an ability to refuse, and that it leads to a murky adulthood of repeatedly saying no when one means yes to friends, lovers, authority figures, one's heart" ( $p$ 77) reading this much, I imagine, could be eye-opening for young parents who are stranded between learning from their own experiences and the lack of a satisfactory public debate on parenting in India.

Any retrospective account of a shared parent is complicated by the fact that the same events, especially traumatic ones, are remembered differently. Prabhu and her younger sister $G$ deal with the same parents, attend the same funeral, grow up listening to the same stories. $\mathrm{G}$ is Prabhu's rock solid support, but their life trajectories are different, as are their ways of remembering, grieving and coping. How then does one write a genre that audaciously claims 'this really happened'? Prabhu is careful to never present her truth as the truth, but in India, the stakes of writing a memoir are high not only because memory is partial. As Prabhu perceptively puts it, "And I know why there are such few memoirs being written in this country about the sort of suffering that only families can inflict and endure. The rhetoric of duty, sacrifice and family honor turns ceaselessly like a giant oil press" (pp 124-5). If I had to tell it again is a compassionately written contradiction because it is a memoir that goes beyond this rhetoric - a must-read because it embraces the need to be just to oneself when life is not kind.

\section{Reference}

1. Ge K. Gayathri Prabhu's If I Had To Tell It Again narrates a story of extraordinary suffering and love. Firstpost.com. 2018 Jan 7[cited 2018 Jul 10]. Available from: https://www.firstpost.com/living/gayathri-prabhusif-i-had-to-tell-it-again-narrates-a-story-of-extraordinary-sufferingand-love-4288753.html

\title{
An editor speaks: Setting the record straight
}

\section{SANJAY A PAI}

\section{Jerome $P$ Kassirer, Unanticipated outcomes: A medical memoir. Wellesley, MA; Jerome P Kassirer, 2017, pp x + 172, USD 35, Kindle Rs 449, ISBN 978-0-692-80871-9.}

\footnotetext{
Author: Sanjay A Pai (sanjayapai@gmail.com), Consultant Pathologist and Head of Pathology, Columbia Asia Referral Hospital, Malleswaram, Bengaluru 560055 , INDIA.

To cite: Pai SA. An editor speaks: Setting the record straight. Indian J Med Ethics. 2018 Oct-Dec;3(4)NS:340-2.DOI:10.20529/ IJME.2018.055.

Published online on July 13,2018.

OIndian Journal of Medical Ethics 2018
}

An opportunity to read the memoirs of one of the most famous medical editors of our times, of one of the most prestigious medical journals of all time, was not something I could pass up. Thus, it was with glee and curiosity that I took up the job of reading and reviewing the memoirs of Dr Jerome Kassirer, former editor-in-chief of the New England Journal of Medicine (NEJM).

Jerry Kassirer was editor of the journal from 1991 to 1999, and a considerable part of the book - and its raison d'etre - explores those eight years. However, it begins with a brief interesting history of the NEJM and is followed by the story 
of Kassirer's youth in an atmosphere quite different from the rarefied one of the NEJM. His anecdotes illustrate the stiff competition and the high standards that exist in medical education in the USA. The first half of the book discusses his life up to the time he appeared for the series of interviews to pass the litmus test to become editor, as well as his first foray into the offices of the journal.

Kassirer became editor during times that were clearly a-changing. It was a decade where there was a heightened awareness of the medical-industrial complex and growing concerns over commercial interests in medicine. A shift in medical thinking had occurred as medical societies and associations started to see themselves more as businesses generating income and pursuing profit to justify their organizations' very existence. We now see this phenomenon in India and Kassirer's concerns over the business interests that can affect medicine and patient care is a salient part of his narrative.

Kassirer's memoirs make clear that there is more to medicine than science. His editorials - penned from what he calls the "Bully Pulpit"- engaged social and political issues that were relevant to the health and welfare of the public. Almost five pages in these memoirs are dedicated to the uniquely American problem of guns and the gun lobby. Kassirer explains how powerful and influential the gun lobby is and why it is difficult to solve this issue. He also raised ethical concerns about the inequitable structure of a health system where planned managed care - while generous in some areas of medicine - could restrict needed treatment through caps in other areas. Kassirer questioned the status quo when it clashed with the public interest. And his editorials challenged the medical community to ponder its professional integrity and commitment to patients when healthcare was treated as a commodity driven by market values.

Kassirer's ruminations on conflict of interest (COI) are also informative and offer insight into a vexing issue that the medical community continues to wrestle with. Journals and speakers now declare COIs. The NEJM was at the forefront of this policy. But it also highlighted - through articles and editorials - the limits of disclosure in addressing COI. Biases that might be attached to a $\mathrm{COI}$ can work unconsciously. Disclosing a COI is necessary. But as Kassirer points out, disclosure simply draws attention to a possible bias and nothing more. It does not neutralise a bias. Nor does it imply a bias must be at work. Determining whether medical information or point of view was tainted by bias, Kassirer informs us, can be a tricky business.

To ensure integrity and objectivity in what it published, the NEJM raised the ethical bar by introducing a COI policy that restricted experts writing editorials and review articles from having a commercial $\mathrm{COI}$ that was related to what they wrote about. The policy - implemented by Kassirer's predecessor, Arnold Relman, aligned the NEJM's COI policies with other professions such as law and journalism. Still, this ruffled feathers in the medical establishment and some heated exchanges ensued in print between the NEJM and distinguished members of the medical community. The policy was strongly endorsed by Kassirer when he took the reins as editor-in-chief.

But it was eventually watered down by the current editor Jeffrey Drazen, not long after Kassirer left the journal. Drazen claimed the policy was changed because it was too difficult to find experts free of a financial conflict (1). Kassirer noted publicly that the change was "misguided" and that nonconflicted experts could be found with greater effort.

After his departure from the NEJM, Kassirer continued to write about commercial COI. Discussions about commercial COIs tended to focus on whether they were being disclosed or not. Kassirer saw this "obsession" with disclosure as a distraction from the real problem - the commercial COls themselves. In other words, we were often missing the wood for the trees.

The issues that Jerry Kassirer takes up in his memoir are far from being alien to us in India. Concerns about commercial $\mathrm{COI}$ and the long drawn out battle between the Indian Medical Association (and the Medical Council of India) and Dr KV Babu about medical societies endorsing commercial products (2) is only too fresh in our minds. (For the benefit of readers outside India - in that case, the Indian Medical Association had endorsed products of Pepsico, which Dr Babu saw as an infringement of the duties of a medical association and complained to the Medical Council of India. For pointing this out, he was harassed and practically considered persona non grata by both groups. In 2016, however, after a torrid eight years, the Parliamentary Standing Committee on Health absolved him of any possible wrongdoing. (2)

Against this backdrop, Kassirer's account of his resisting ongoing pressures from the NEJM's owners to use the journals' reputation as a marketing tool to increase profits makes for compelling reading. As a result of his resistance, Kassirer was ultimately sacked by the Massachusetts Medical Society - the owner and publisher of the journal. He attributes his firing to his obstinate and obstructionist character. This will also likely resonate with those who are sympathetic to the IJME. We too have been called obstinate and unreasonable, unable to keep up with the times and living in a fool's world because of our attempt to remain independent and free of commercial influence. Kassirer is, alas, an endangered medical species, the old-fashioned physician - not in the sense of being a Luddite, but rather in terms of being honourable, trustworthy, and pursuing patient's interests over all else.

I was also delighted to read Kassirer's comments on modern technology and medicine. The positives of technology are obvious to all. But it's the mindless application of technology (in part because of defensive medicine and perhaps in equal part, a reflection of the laissez faire attitude that many physicians now have) that worries Dr Kassirer. This shotgun approach is unscientific and raises ethical concerns about patients receiving medical interventions lacking an evidence base - not to mention the exorbitant costs and financial stresses that such practices can place on patients 
and healthcare systems. Kassirer sees a need to completely overhaul medicine.

Some episodes in the book would have been funny, had they not been tragicomic. One of them, towards the end of the book, is about Dr Kassirer, in his post-editor days, going to deliver a talk on conflict of interest.....and learning that the talk was to be preceded by food sponsored by a drug company!

To those who still believe that they are not influenced by pharma, (and commercial interests), I am reminded of a statement by a friend who is in marketing, "You think you are not influenced. We know better. We are not fools. In fact, we have the data to show how you are influenced by our marketing". Unfortunately, this view has been borne out by high profile scandals where marketing and financial conflicts played a key role in promoting tainted medical information that had dire consequences for the public. $(3,4)$

Something I would like to have seen explored more in the book has to do with influences on Kassirer. I was left wondering what makes Dr Kassirer a physician of such values? We know about some of his mentors in medical school. But how did his parents influence him? What books made an impression on him? What are his hobbies (apart from photography)? Have his nonphysician friends' opinions resulted in his changing his views?
Studying the lives of achievers is always instructive, and this book is no different. I have read biographies and autobiographies of pathologists, orthopaedic surgeons, surgeons, general practitioners and physicians. But this is the first I have read of a medical editor. It is a fascinating read about a highly respected editor who clearly loves medicine and is passionate about trying to preserve and enhance its professional integrity. I strongly recommend it to all editors (not just medical!). Besides editors, if you happen to be a medical teacher, a doctor, an ethicist or a media person, you should read the book. In fact, if you like a rollicking story and a no-holds-barred book, this one is for you.

\section{References}

1. Drazen JM, Curfman GD. Financial associations of authors. N Engl J Med. 2002 Jun 13;346(24):1901-2.

2. Special Correspondent. Whistleblower doctor wins battle against $\mathrm{MCl}$. Thehindu.com. 2016 May 9[cited 2018 Jul 9]. Available from: https:// www.thehindu.com/news/cities/Thiruvananthapuram/whistleblowerdoctor-wins-battle-against-mci/article8329641.ece

3. Meier B, Saul S. Marketing of Vioxx; How Merck played game of catchup. New York Times. 2005 Feb 11[cited 2018 Jul 9]. Available from: https://www.nytimes.com/2005/02/11/business/marketing-of-vioxxhow-merck-played-game-of-catchup.html

4. Zee AV. The promotion and marketing of OxyContin: Commercial triumph, public health tragedy. Am J Public Health. 2009 Feb;99 (2):221-

\section{APPEAL FOR DONATIONS TO THE FORUM FOR MEDICAL ETHICS SOCIETY}

The Forum for Medical Ethics Society (FMES), publisher of the Indian Journal of Medical Ethics (IJME), appeals to subscribers, contributors, readers, supporters and well-wishers of IJME and FMES to donate to its corpus and towards the publication of IJME. Contributions from both individuals and institutions are welcome.

FMES has published the journal on a shoestring budget, without a break, since 1993. The journal is known for being open access and spearheading discourse aimed at advancing social justice in health and ethics-centred healthcare and health research reform. It is recognised widely as an authoritative resource of knowledge in bioethics and allied areas of enquiry. FMES and IJME have not only sustained themselves but have grown over these past 25 years. Our ever-growing base of readers, contributors, and reviewers enables the publication of multiple and diverse perspectives on wide-ranging topical areas. We have also striven to upgrade the journal technically to keep up with the advances in publishing to widen our reach. This has been possible only because of your steadfast and sustained support.

We are committed to maintaining our editorial independence which is critical to safeguarding the scientific integrity of what we publish. Therefore, wider support from all those who are committed to social justice in health is essential.

FMES is registered under the Societies Registration Act, 1860 (Reg No: Mumbai-218-1995-G.B.B.D.D) and the Bombay Public Trusts Act, 1950 (Reg No: F-17441 Mumbai, 1995), and donations are eligible for tax exemption under Section 80G of the Income Tax Act, 1961

For more details on how to support us, write to fmesmumbai@gmail.com or visit our website www.ijme.in/subscribe-support/

SUPPORT OPEN-ACCESS ACADEMIC PUBLICATIONS, DONATE TO THE FMES CORPUS FOR THE PUBLICATION OF IJME! 